\title{
The Determination of a GSM Operator Preference with a Multiple Logistic Regression Analysis: A Youth-Oriented Study at a University in Turkey
}

\author{
Emre Yakut ${ }^{1}$, Ayhan Demirci ${ }^{2} \&$ Erhan $_{\text {Ergin }^{3}}$ \\ ${ }^{1}$ Faculty of Economics and Administrative Sciences, Department of Management Information Systems Osmaniye \\ Korkut Ata University, Osmaniye, Turkey \\ ${ }^{2}$ Faculty of Economics and Administrative Sciences, Department of International Trade And Logistics, Toros \\ University, Mersin, Turkey \\ ${ }^{3}$ Faculty of Economics and Administrative Sciences, Department of Business Administration, Osmaniye Korkut \\ Ata University, Osmaniye, Turkey \\ Correspondence: Emre Yakut, Faculty of Economics and Administrative Sciences, Department of Management \\ Information Systems Osmaniye Korkut Ata University, Osmaniye, Turkey. Tel: 90-328-815-1818. E-mail: \\ emreyakut@osmaniye.edu.tr
}

Received: May 16, 2016

doi:10.5539/res.v8n3p316
Accepted: June 15, 2016

Online Published: August 11, 2016

URL: http://dx.doi.org/10.5539/res.v8n3p316

\begin{abstract}
The magnitude of technological developments can be better understood nowadays in line with the developments particularly in the communication and mobile phone industries. These developments do not only trigger the production of new technology for mobile phones but they also bring forward the issue of conveying this technology to users. The applications and services produced for mobile phones are generally introduced to the market via Global System for Mobile Communications (GSM) operators providing communication services. Users' benefiting from these applications and services in their mobile phones or from their operators, depends on their preference of a GSM operator that has the capacity to meet the users' needs. This study has aimed to determine the factors that influence the preference of a mobile phone operator among university students, the most active age group using mobile phones. Both factor analysis and multiple logistic regression analysis are used to determine the influential factors and the degree of influence in the preference of a GSM operator. It has been identified that the most influential variable on the preference of a GSM operator is the communication expenses as a socio-economic factor, whereas the brand factor is the most important variable in deciding which GSM operator service to purchase.
\end{abstract}

Keywords: GSM operator, GSM preference, multiple logistic regression analysis

\section{Introduction}

Communication is an extremely important concept emerging together with the history of humanity. Long before the mobile phones were introduced to the market, many different means of communication had been used to establish communication via smoke, messenger pigeons, letters, telegrams, radios, telephones, faxes, and televisions, which have changed and developed until today. Mobile phones became one of the means of communication at the beginning of the 1990s. Only certain people could use mobile phones when they were first introduced to the market, whereas today it is an indispensable part of daily life, and the number of users is expressed in billions worldwide. The enormous demand for mobile phones as well as the appealing prices offered to the companies by the mobile communication market, which is composed of the service providers, has led to the increase in the number of GSM companies.

Three important operators-Turkcell, Vodafone and Avea-operate in the mobile communication market in Turkey. Electronic communications industry market data in Turkey in the third quarter of 2014, issued by the Information and Communication Technologies Authority (BTK) show that there are 71,908,742 mobile phones, and $48.3 \%$ of the subscribers use Turkcell, $29.1 \%$ of them use Vodafone, and $22.5 \%$ of them use Avea (BTK, 2014, pp. 3-50). In the GSM industry, an important factor that influences the operation preference is that new subscribers research about the number of existing subscribers of the GSM companies. In the GSM industry, it is 
of great importance for a firm to acquire new subscribers and protect their available subscriber portfolio from the new strategies of their rivals in parallel with the market growth in order to be able to compete and survive in the long run (Aydın, Özcan, \& Yücel, 2007, p. 220). Mobile Number Portability (MNP) system has provided the users with opportunities and facilities by enabling them to change their operator as they wish and free of charge and without a number change since 2008 (Erginel, Çakmak, \& Şentürk, 2010, p. 82). GSM operators offer competitive advantages through campaigns aiming to increase the number of available subscribers. As a result of the rivalry, mobile phone subscribers benefit from cheaper communication opportunities (Dündar \& Ecer, 2008, pp. 196-197). GSM operators must conduct research on which products or services are preferred in order to increase their market share in the communication industry with the purpose of becoming competitive and successful (Kizgin, 2008, p. 144). In the GSM industry, further studies must be conducted in order to minimize the possible risks that may take place in this business, and to maximize the benefits that are acquired with the aim of making policies regarding the recent developments (Karagöz, Çatı, \& Koçoğlu, 2009, p. 7). With the market having reached to a level of satisfaction, consumer loyalty has become an important concept in the GSM industry since acquiring new subscribers and potential customers of other operators is quite tiresome and costly (Barutçu, 2007, p. 350). Business organizations provide services, considering the socio-demographic features of the customers in order to establish a loyal customer group. Given this viewpoint, GSM operators tend to constitute a customer portfolio, taking into consideration different services and promotion activities especially for university students (Savaşçı \& Günay, 2008, p. 252).

This study aims to identify the factors that influence the preference of a mobile phone operator among university students who commonly use mobile phones, and the effect levels of these factors. In recent years, competitive struggle has been observed to acquire more customers from among the operators in the mobile communication industry in our country. Within this struggle, companies departmentalize the market, and offer a variety of campaigns for the users with different profiles. Within this framework, there is a large customer mass of university students involving young people between 18 and 25 of age, for whom GSM operators organize special campaigns, and on whom companies concentrate their marketing activities. Given the factors such as university students' intensive use of internet in their mobile phones, and became distanced from their families or relatives while studying at university, it is clear that university students are one of the groups who need mobile communication most. Suggestions based on the opinions of this dynamic and innovative group about their preference of an operator are of great importance with regards to directing the marketing strategies of the GSM companies. This study, aims to identify the factors that influence the preference of a GSM operator among university students, and a multiple logistic regression analysis was performed in order to identify the effect levels of these factors.

\section{Literature Review}

Pakola et al. (2003), identified that the three factors deemed most important by the users with respect to the influence on their preference of a mobile phone operator are fee, audibility, and the brand of the operator used by their inner circle. However, Özer et al. (2006) used a binary logistic regression analysis to identify the social and economic factors that influence the university students' preference of a mobile phone line. As a result of the analysis, the authors identified that the level of mobile phone expenses, the number of siblings studying at school, and gender variables are influential on the preference of a mobile phone line. In his study carried out for university students, Barutçu (2007) asserted that the most important factors influencing the preference of an operator are low cost toll calls, the GSM operator used by friends and family, and large coverage zone according to the region they reside. Additionally, it has been observed that suggestions from friends and promotion of the GSM operators are the least effecting factors on the preference of an operator. On the other hand, in a study by Felek et al. (2007) the criteria influencing the users in choosing a GSM operator were specified, after which they were used to predict the market share of the GSM operators in Turkey through Analytical Hierarchy Process (AHP) and Analytical Network Process (ANP) methods, and then the methods were benchmarked. The study showed that ANP is a better method in predicting the market share. Unlike the previous study, Dündar et al. (2008) used the AHP method, and listed the GSM operators based on the criteria specified for university students' purchasing mobile phone line. As a result of their analysis, the order of preference for GSM operators was Turkcell, Vodafone and Avea, successively. In a field study conducted by Kizgin (2008) on specifying the variables influencing university students' operator preference, the author made an analysis of the data involving demographic information, socio-economic situations and GSM subscriptions of university students by using parametric and nonparametric statistical methods. Also, it was stressed that the factors influencing the GSM preference are network coverage, the effect of customer services, the suitability of tariffs, the effect of reference groups like family and friends, and additional services provided for the users. On the other hand, Savaşçı et al. 
(2008) stated that the most fundamental elements on university students' preference for a GSM operator are the service quality, advantages of the product, and fee. Karagöz et al. (2009) analyzed whether demographic factors influence university students' mobile phone and operator preferences, by using Kruskal-Wallis and Mann Whitney U non-parametric techniques. Erginel et al. (2010) studied on the expected market share by applying the blurred TOPSIS method on the data obtained from preference criteria of the GSM operator customers utilizing the number portability system. As a result of the research, $41 \%$ of the customers stated that they prefer Avea, 33\% preferred Turkcell, and 32\% Vodafone. Similarly, in a study conducted by Rahman et al. (2010) on GSM subscribers in Malaysia, the authors stated that price or call fee is the most important factor in operator preference, followed by service quality, service accessibility, and promotional factors, successively. Dadzie and Mensah (2011) identified that the most important factors on the preference for a mobile phone operator are promotion, fee and product availability variables, successively. Gautam and Kumar (2011) analyzed the factors influencing the consumers' preference for a mobile service provider. The authors also emphasized in the study, in which explanatory factor analysis and structural equation model methods were used, that price of the product, product quality and accessibility, service quality and promotion are the very factors that affect the preference of a service provider. Paulrajan and Rajkumar (2011) indicated that product quality and accessibility have significant impacts on consumers' perception in choosing a mobile service provider, and communication and fee are also the most influential factors. Hemmati et al. (2012) used the AHP method, and mentioned that the most important variables influencing the GSM operator preference are customer satisfaction and word of mouth communication in the study conducted in Iran. Likewise, Karaçuka et al. (2012) indicated that the effect of regional network coverage and consumer characteristics have significant impacts on the consumers' preference for a mobile operator. Additionally, Shah (2012) emphasized that service quality and brand image, service fees and network quality are influential on participants' choice of a mobile operator, successively. Olatokun and Nwonne (2012) asserted that call fee, service quality, service accessibility, and brand image are important factors in choosing a GSM operator. Hassan et al. (2013) applied the AHP method with the purpose of identifying university students' GSM operator preference in Malaysia. As a result of the study, it was observed that students preferred Celcom, Maxis and DiGi, successively. Öztürk et al. (2013) applied factors analysis in order to specify the variables influencing GSM operator preferences of university students. The analysis showed that the tariff variety and service quality, special campaigns for groups, and content of advertisements are influential in choosing an operator. Atmaca and Keskin (2014) conducted research on customer satisfaction of GSM operator users by using a Chi-square test. Accordingly, the authors concluded that the customer satisfaction levels of Vodafone users are higher than that of Turkcell and Avea users. In a study conducted by Maksüdünov (2014) in Kirghizstan on mobile phone users, the author analyzed the factors influencing the customers' operator preferences by using multi-class logit model. The research results signified that demographic features, income level of customers and service quality are influential on GSM operator preference. Okeke (2014) also analyzed the factors influencing the GSM service provider preferences of the employees in a study conducted with petrol and fuel gas workers in Nigeria. The research showed that the most influential factors were network coverage, network quality, tariff/call fees and customer services, successively.

\section{Methodology}

Logistic regression analysis is a statistical technique with multiple variables expressed as discrete variables that belong to two or more classes. In the case that the dependent variable is a discrete variable, the Logistic or Probity regression methods are preferred. The aim of the logistic model is to build a model to explain the relationship between the dependent and independent variables depending on the number of categories of the dependent variable, i.e., two or more (Ar1 \& Önder, 2013).

Logistic regression analysis shares some hypotheses of the normal regression analysis (Field, 2009):

Linearity: In a normal regression analysis, it is assumed that there is a linear relationship between the estimators and results. However, in a logistic regression analysis, this hypothesis is violated for the reason that categorical variables are used herein. Within the logistic regression analysis, the linearity hypothesis assumes that there is a linear relationship between a constant determinant and the result variable.

Independence of Errors: It refers to the same assumption stated for the normal regression analysis. Basically, data files are not related to each other. For example, a measure about the same individual cannot be made at different times.

Multiple Linearity: A high correlation must not be expected among the estimators. As is the case in normal regression analysis, this assumption can be controlled via scaled statistics such as tolerance and some condition indices, or variance rates. 
Logistic regression analysis is a technique used to determine the reason-result relationship between the dependent variable and independent variables without the necessity of a normal distribution hypothesis as long as the dependent variable is categorical and independent variables are constant or categorical, as well to explain the effect levels of the independent variables, and classify the dependent variables (Türe et al., 2005).

However, if some of the independent variables such as race, gender, and treatment group, etc., are discrete nominal variables then it will not be appropriate to include them into the same model as if they were interval scales because the numbers showing a variety of levels are only determinants, and they do not have any numerical significance. In this case, the method to be chosen will utilize the cluster of "intended variables" (Hosmer \& Lemeshow, 2000). For example, if the existence of a patient's tumor is less likely, then the doctor will not probably need a costly and painful operation. Though such vital decisions are not quite often encountered, logistic regression analysis produces fairly useful results. When the estimation of a two-categorical variable is aimed, the method to be used is binary logistic regression analysis, whereas multiple logistic regression analysis will be more suitable for estimating more than two categorical variables (Field, 2009).

For example, when one of the independent variables is race, and shown as "black", "white" and "others", then two intended variables will be required. Dependent variable has three categories such as $y=0,1,2$. In this case, two different logistic models will be acquired, one of which is $y=1$ versus $y=0$, and the other one is $y=2$ versus $\mathrm{y}=0$. In other words, a logistic function is produced, comparing $\mathrm{y}=2$ versus $\mathrm{y}=1$, with $\mathrm{y}=0$ as a reference group (Ürük, 2007).

Herewith, the logit model that belongs to the $\mathrm{p}$ variable, whose $\mathrm{j}$ time's independent variable is a discrete value is, expressed as follows (Hosmer \& Lemeshow, 2000, pp. 31-33):

$$
g(x)=\beta_{0}+\beta_{1} X_{1}+\beta_{2} X_{2}+\sum_{l=1}^{k_{j-1}-1} \beta_{j i} D_{j L}+\beta_{k} X_{p}
$$

In such cases, two functions are attained as stated above, which are:

$$
\begin{aligned}
& \Omega_{1}(X)=m\left[\frac{P(Y=1 \mid X)}{F(Y=0 \mid X)}\right]=\beta_{1 n}+\beta_{11} X_{1}+\beta_{12} X_{n}+\cdots+\beta_{19} X_{n}=X^{r} \beta_{1} \\
& \left.\sin (X)=\operatorname{mn}\left[\frac{P(Y=2 ! X)}{N(Y-\varnothing \mid X)}\right]=\beta_{20}+\beta_{21} X_{1}+\beta_{22} X_{2}+\cdots+\beta_{2 g} X_{2}=X^{r} \beta_{2}\right)
\end{aligned}
$$

Accordingly, conditional probability for the each output category is indicated as follows:

$$
\begin{aligned}
& P\left(Y=0(X)=\frac{1}{1+e^{S_{1}(X)}+\epsilon^{G_{2}(X)}}\right. \\
& P(Y=1 \mid X)=\frac{e^{g_{1}(X)}}{1+e^{S_{1}(W)}+g^{\operatorname{Si}(W)}}
\end{aligned}
$$

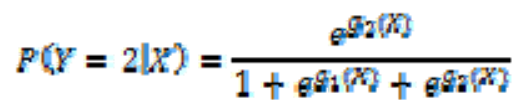

Thereby, if the conditional probability in these three categories is stated as;

\section{$\beta_{0}=0$ and $g_{0}(X)=0$ :}

then it is generalized as follows (Hosmer \& Lemeshow, 2000, pp. 261-262):

$$
P(Y=j \mid X)=\frac{\epsilon^{g i}(X)}{\sum_{k=0}^{2} e^{9 k}(X)}
$$

In a multiple logistic regression analysis, any category of the result variable is indicated as a reference category, and all other categorical levels are compared with this reference. The choice of the reference category depends on the appreciation of the researcher (Kleinbaum \& Klein, 2010). The aim of this study is to identify effectively the demographic and socio-economic factors that influence the preference of a mobile phone operator among university students as well as brand, fee, promotion and service factors that influence their purchasing decision, and to determine the effect levels of these factors. The research sample involves the students studying at Osmaniye Korkut Ata University. 


\subsection{Data Set}

The data used in the study is obtained via the questionnaire filled out by students studying at Osmaniye Korkut Ata University. As of 2014, the number of students at the university is 10,426 and a 528 students responded to the questionnaire, and 400 questionnaires were evaluated with the exclusion of approximately 128 questionnaires which had missing and/or erroneous information. The minimum number of questionnaires to be applied in the study was estimated with the help of the following formula (Özer, 2004):

$$
n=\frac{N P Q Z^{2}}{(N-1) \cdot d^{2}+P Q z^{2}}
$$

In the formula; $n:$ sample size, $N:$ groundmass size, $P_{n}$ likelihood of a given phenomenon, $Q=1-P, Z$ value $(1-\kappa)$ refers to the confidence level test statistics and $d$ is the amount of tolerance. In this case, the least representative sample size in the questionnaire is estimated as follows: the size of the representative sample has been estimated as 371 with $5 \%$ of significance level and $5 \%$ of the amount of tolerance.

$$
n=\frac{10426(0.5)(0.5)(1.96)^{2}}{(10426-1) 0.05^{2}+(0.5)(0.5)(1.96)^{2}} \cong 371
$$

In this study, multiple logistic regression analysis was used in order to identify the factors influencing the GSM operator preference and their effect level. Considering the demographic and socio-economic variables of the students in the survey, frequency and percentage distribution was given. Pearson Chi-square $\left(x^{2}\right)$ statistics was performed to reveal the relationship between the variables and GSM operator preferences. Also, factor analysis was made in order to determine the factors influencing the GSM operator purchasing decision. The scores obtained from these factors were taken as an independent variable in order to use them later in the multiple logistic regression model. Table 1 shows frequency and percentage values of students' demographic and socio-economic features.

Table 1. Frequency and percentage of values of students' demographic and socio-economic features with

\begin{tabular}{|c|c|c|c|c|c|}
\hline Variables & & & Variables & & \\
\hline Gender & $\mathrm{N}$ & $\%$ & Education Type & $\mathrm{N}$ & $\%$ \\
\hline Female & 213 & 53.2 & Normal Education & 139 & 34.8 \\
\hline Male & 187 & 46.8 & Evening Education & 261 & 65.2 \\
\hline Age & & & Faculty & & \\
\hline $18-21$ & 228 & 57 & Faculty of Engineering & 145 & 36.3 \\
\hline $22-25$ & 153 & 38.2 & Faculty of Sciences and Literature & 103 & 25.7 \\
\hline 26 and over & 19 & 4.8 & Faculty of Economics and Administrative Sciences & 152 & 38 \\
\hline Years of Using a Mobile Phone & & & Use of a smart phone & & \\
\hline Less than 1 year & 15 & 3.8 & Yes & 274 & 68.5 \\
\hline Between 2 and 5 years & 113 & 28.2 & No & 126 & 31.5 \\
\hline Between 6 and 9years & 184 & 46 & GSM subscription type & & \\
\hline 10yearsand over & 88 & 22 & Postpaid Line & 98 & 24.5 \\
\hline Mean communication expenses & & & Prepaid Line & 302 & 75.5 \\
\hline Less than $20 \mathrm{TL}$ & 100 & 25 & GSM Operator & & \\
\hline Between 20 and $39 \mathrm{TL}$ & 250 & 62.5 & Avea & 164 & 41 \\
\hline Between 40 and $59 \mathrm{TL}$ & 33 & 8.3 & Turkcell & 96 & 24 \\
\hline $60 \mathrm{TL}$ and over & 17 & 4.2 & Vodafone & 140 & 35 \\
\hline \multicolumn{6}{|l|}{ The most frequent GSM service } \\
\hline Texting & 127 & 31.7 & & & \\
\hline Speaking & 184 & 46 & & & \\
\hline Internet & 89 & 22.3 & & & \\
\hline
\end{tabular}
reference to the GSM operators 
As can be seen in Table 1, of all the students taking part in the questionnaire, $53.2 \%$ were female, $46.8 \%$ were male; $57 \%$ were in the age group of $18-21,38.2 \%$ were in the age group of $22-25,4.8 \%$ were 26 years of age and over. In the questionnaire, $34.8 \%$ of the students have normal education whereas $65.2 \%$ of them study at evening education; $36.3 \%$ of them study at the faculty of engineering, $25.7 \%$ of them study at the faculty of sciences and literatures, $38 \%$ of them study at faculty of economics and administrative sciences. Of all the students, $68.5 \%$ of them use smart phones whereas $31.5 \%$ of them do not. Evaluating the length of period, $3.8 \%$ of the students have used mobile phones less than one year, $28.2 \%$ have used them for about 2 to 5 years, $46 \%$ of them have used mobile phones for about 6 to 9 years, and $22 \%$ have used for 10 years or more. When the mean communication expenses of the participants were evaluated, $25 \%$ of them pay less than $20 \mathrm{TL}, 62.5 \%$ of them pay between 20 and $39,8.3 \%$ pay between 40 and $59 \mathrm{TL}$, and $4.2 \%$ pay $60 \mathrm{TL}$ and over. As to the most frequent service type that students use, the percentages differ as $31.7 \%$ of texting, $46 \%$ of speaking and $22.3 \%$ of internet use. When considered in terms of subscription, $24.5 \%$ of the students have postpaid lines whereas $75.5 \%$ of them have prepaid. On the other hand, based on the data obtained from the students, $41 \%$ of them use Avea, $24 \%$ of them use Turkcell and $35 \%$ of them use Vodafone operator. Table 2 shows the $x^{2}$ values between the GSM operators, and demographic and socio-economic variables.

Table 2. Analysis results about the person Chi-square $\left(x^{2}\right)$

\begin{tabular}{llll}
\hline Variable & Pearson Chi-square $\left(X^{2}\right)$ & Degree of Freedom $(\mathrm{df})$ & $\mathrm{P}>X^{2}$ \\
\hline Age of the student & 8.996 & 4 & $0.061^{* * *}$ \\
Faculty & 18.108 & 4 & $0.001^{*}$ \\
Education type & 0.774 & 2 & 0.679 \\
Total time of owning a mobile phone & 9.993 & 6 & 0.125 \\
Whether they use smart phones & 2.198 & 2 & 0.333 \\
Type of GSM subscription used & 3.529 & 2 & 0.171 \\
Communication expenses & 16.977 & 6 & $0.009^{*}$ \\
$\begin{array}{l}\text { Use of the frequent service type provided } \\
\text { by the GSM operator }\end{array}$ & 16.292 & 4 & $0.003^{*}$ \\
\hline $01 * * 0.05 * * * 10$ significance level. & & & \\
\hline
\end{tabular}

$* 0.01 * * 0.05 * * * 0.10$ significance level.

The relationship between the students' GSM operator preference (Table 2), and demographic and socio-economic variables was analyzed using Pearson $\left(\chi^{2}\right)$ testi. A statistically significant relationship was identified between the variables including the age of the students, the faculty they study at, the communication expenses, the most frequent service type that they receive from the GSM operator, and their GSM operator preferences.

\subsection{Identifying the Factors That Influence GSM Operator Purchasing Decision of the Students Participating in the Survey}

The factor analysis was performed with 23 questions that influence GSM operator purchasing decision of the university students. The relevant questions used in the questionnaire were formed after a detailed literature review. In this framework, the questionnaire was formed according to the content, which involves a 4-point scale for the brand factor (Ofwona, 2007; Felek et al., 2007; Savaşç1 et al., 2008; Hemmati et al., 2012); a 4-point scale for the fee factor (Aydın et al., 2007; Savaşçı, 2008); a 6-point scale for the promotion factor (Aydın et al., 2007; Ulaşanoğlu, 2005; Felek et al., 2007; Kızgın, 2008; Karagöz et al., 2009) and a 9-point scale for the service factor (Ofwona, 2007; Savaşçı, 2008; Türkay, 2011; Murthy et al., 2011; Hemmatiet al., 2012; Karaçuka et al., 2012; Shah, 2012).

Kaiser-Meyer-Olin (KMO) test was performed to test the suitability of the data to the factor analysis. As a result of the factor analysis, KMO value was 0.717 , and because the p value was $p=0.00 \leqslant 0.01$, it wasstatistically significant, which showed that the factor analysis could be performed. As a result of the factor analysis, Varimax Rotation option was used, and 4 factors, whose factor load values were over 0.70 , were specified with the 9 questions after excluding 14 questions out of 23 questions. These factors include Brand, Fee, Promotion and Service factors. Cronbach Alpha coefficient was calculated to perform the reliability analysis of these 4 factors, 
and found over 0.70 . Table 3 shows the analysis results of the factors that influence the GSM operator purchasing decisions of students.

Table 3. Identifying the factors that influence the GSM operator purchasing decisions

\begin{tabular}{llll}
\hline & $\begin{array}{l}\text { Factor } \\
\text { Burden }\end{array}$ & $\begin{array}{l}\text { Alpha } \\
\text { Coefficient }\end{array}$ & $\begin{array}{c}\text { Explained } \\
\text { Variance }\end{array}$ \\
\hline $\begin{array}{l}\text { 1. Brand Factor (Latent Value: 3.055) } \\
\text { Effective information about the firm accessible via the Internet }\end{array}$ & 0.831 & 0.758 & 23.61 \\
Existence of a perception of a reliable firm & 0.776 & \\
Big market share of the company & 0.751 & \\
2. Fee Factor (Latent value: 1.608) & & 0.767 & 18.26 \\
Low Tariff Costs & 0.900 & & \\
Tailor-maid Promotion Offers & 0.827 & & \\
3. Promotion Factor (Latent value: 1.106) & & 0.737 \\
High number of customers & 0.858 & & \\
Company's Attracting Promotions & 0.720 & & \\
4. Service Factor (Latent value: 0.997$)$ & & 0.721 & \\
High Internet Access Speed & & & \\
Rich Tariff Variety & 0.882 & & \\
\hline
\end{tabular}

*Scale: 1. I Strongly Disagree, 5. I Strongly Agree.

As seen in Table 3, four factors that influence the GSM operator purchasing decision were identified, and it was ascertained that these factors explained the $74.86 \%$ of the total variance. According to the factor analysis results, the most important factor that influence the GSM operator purchasing decision is the brand factor with an explanation rate of $23.61 \%$, the second is the fee factor with an explanation rate of $18.26 \%$, the third is the promotion factor with an explanation rate of $18.13 \%$, and the fourth one is the service factor with an explanation rate of $14.86 \%$. The scores of these four factors were taken as an independent variable in order to use them in the multiple logistic regression model.

\subsection{Multiple Logistic Regression Analysis Results for the GSM Operator Preference}

In this part of the study, multiple logistic regression analysis was performed by using the STATA 11.2 statistics package programmed in order to determine the factors that influence the GSM operator preference of the students and the effect levels of these factors. The suitability values of multiple logistic regression model, goodness of fit test results, Wald test results for the independent variables and the effect levels of these factors were estimated. Table 4 shows the values of the goodness of fit test performed for the multiple logistic regression model.

Table 4. Data on the goodness of fit of the model designed for the multiple logistic regression

\begin{tabular}{llll}
\hline Log-Lik Intercept Only: & -430.200 & Log-Lik Full Model: & -379.910 \\
\hline D(305): & 759.820 & LR(40): & 100.580 \\
& & Prob > LR: & 0.000 \\
McFadden's R2: & 0.117 & McFadden's Adj R2: & 0.030 \\
Maximum Likelihood R2: & 0.222 & Cragg \& Uhler's R2: & 0.252 \\
Count R2: & 0.470 & Adj Count R2: & 0.102 \\
AIC: & 2.215 & AIC*n: & 885.820 \\
BIC: & -1259.303 & BIC': & 139.078 \\
\hline
\end{tabular}


Table 4 shows the goodness of fit test for the model with the purpose of identifying the effective factors in GSM operator preference of the university students. Akaika Information Criterion (AIC) was determined as 2.215 and Bayes Information Criterion (BIC) was determined as -1259.303, in that low level of AIC and the negative value of BIC of the model indicated that the logit model was at a satisfactory level. The likelihood ratio of the multiple logistic regression model was estimated 100.580. Since $p=0.00 \times 0.01$, the model involving all independent variables were found be statistically significant. In the multiple logistic regression model, all independent variables explained $11.7 \%$ of the possible changes on the GSM operator categorical variable, which was the dependent variable. Table 5 shows the goodness of fit test results for the multiple logistic regression model.

Table 5. Goodness of fit test results for the multiple logistic regression model

\begin{tabular}{ll}
\hline Goodness of Fit Test for the Multiple Logistic Model & \\
\hline Number of Groups & 10 \\
Pearson $\chi^{2}$ Test Statistics & 19.486 \\
Degree of Freedom & 16 \\
$\mathrm{P}>\chi^{2}$ & 0.244 \\
\hline
\end{tabular}

Table 5 also shows that Hosmer-Lemeshow $\left(x^{2}\right.$ test was performed for the goodness of fit of the multiple logistic regression model. It was agreed that the model's data fit was at sufficient level because $\chi^{2}=19.486$ and $P=0.244 \geq 0.05$, and thus the data could be used to analyze the model with respect to the GSM operator preference. Table 6 shows the Walt test results for their dependent variables.

Table 6. Wald test results of the independent variables

\begin{tabular}{|c|c|c|c|c|c|c|c|c|c|c|c|}
\hline & $x^{2}$ & $\begin{array}{l}\text { Degree of } \\
\text { Freedom }\end{array}$ & $\mathrm{P}>\chi^{2}$ & $\begin{array}{l}\text { Independent } \\
\text { Variable }\end{array}$ & $x^{2}$ & $\begin{array}{l}\text { Degree of } \\
\text { Freedom }\end{array}$ & $\mathrm{P}>\chi^{2}$ & $\begin{array}{l}\text { Independent } \\
\text { Variable }\end{array}$ & $x^{2}$ & $\begin{array}{l}\text { Degree of } \\
\text { Freedom }\end{array}$ & $\mathrm{P}>\chi^{2}$ \\
\hline Gender & 2.159 & 2 & 0.340 & $\begin{array}{l}\text { Faculty of } \\
\text { Sciences and } \\
\text { Literature }\end{array}$ & 10.036 & 2 & $0.007^{*}$ & $\begin{array}{l}\text { Speaking } \\
\text { Service }\end{array}$ & 2 & 9.053 & $0.011 * *$ \\
\hline $\begin{array}{l}\text { Education } \\
\text { Type }\end{array}$ & 0.008 & 2 & 0.996 & FEAS & 6.064 & 2 & $0.048^{* *}$ & $\begin{array}{l}\text { Internet } \\
\text { Service }\end{array}$ & 2 & 7.806 & $0.020 * *$ \\
\hline $\begin{array}{l}\text { Use of a } \\
\text { Smart } \\
\text { Phone }\end{array}$ & 0.381 & 2 & 0.826 & $\begin{array}{l}2-5 y e a r s \text { of } \\
\text { age }\end{array}$ & 1.607 & 2 & 0.448 & $\mathrm{BF}$ & 2 & 9.792 & $0.007 *$ \\
\hline $\begin{array}{l}\text { GSM } \\
\text { subscriptio } \\
\text { n type }\end{array}$ & 6.538 & 2 & $0.038^{* *}$ & $\begin{array}{l}6-9 \text { years of } \\
\text { age }\end{array}$ & 0.885 & 2 & 0.642 & $\mathrm{FF}$ & 2 & 0.227 & 0.893 \\
\hline $\begin{array}{l}22-25 \text { of } \\
\text { age }\end{array}$ & 1.621 & 2 & 0.445 & $\begin{array}{l}\text { 10yearsand } \\
\text { over }\end{array}$ & 0.928 & 2 & 0.629 & $\mathrm{PF}$ & 2 & 19.850 & $0.000^{*}$ \\
\hline \multirow[t]{3}{*}{$\begin{array}{l}26 \text { and } \\
\text { overage }\end{array}$} & 0.068 & 2 & 0.967 & $20-39 \mathrm{TL}$ & 0.627 & 2 & 0.731 & $\mathrm{SF}$ & 2 & 1.073 & 0.585 \\
\hline & & & & $40-59 \mathrm{TL}$ & 9.999 & 2 & $0.007 *$ & & & & \\
\hline & & & & Over $60 \mathrm{TL}$ & 1.883 & 2 & 0.390 & & & & \\
\hline
\end{tabular}

$* 0.01 * * 0.05 * * * 0.10$ statistically significant.

Table 6 shows the Wald analysis test performed for the independent variables in the multiple logistic regression model. A hypothesis test was set to determine whether the independent variable coefficients in the model are equal to zero, and to identify the statistically significant variables. Students at the Faculty of Sciences and Literature, phone expenses between 40 and 59 TL, and PF "promotion factor" were at the significance level of 0.01, whereas GSM subscription type was found to be at 0.05 significance level. Speaking service and internet 
service variables were found to be statistically significant for the FEAS students in their GSM operator preferences. Table 7 shows the analysis results of the multiple logistic regression model.

Table 7. Multiple logistic regression analysis results of the factors influencing GSM operator preference

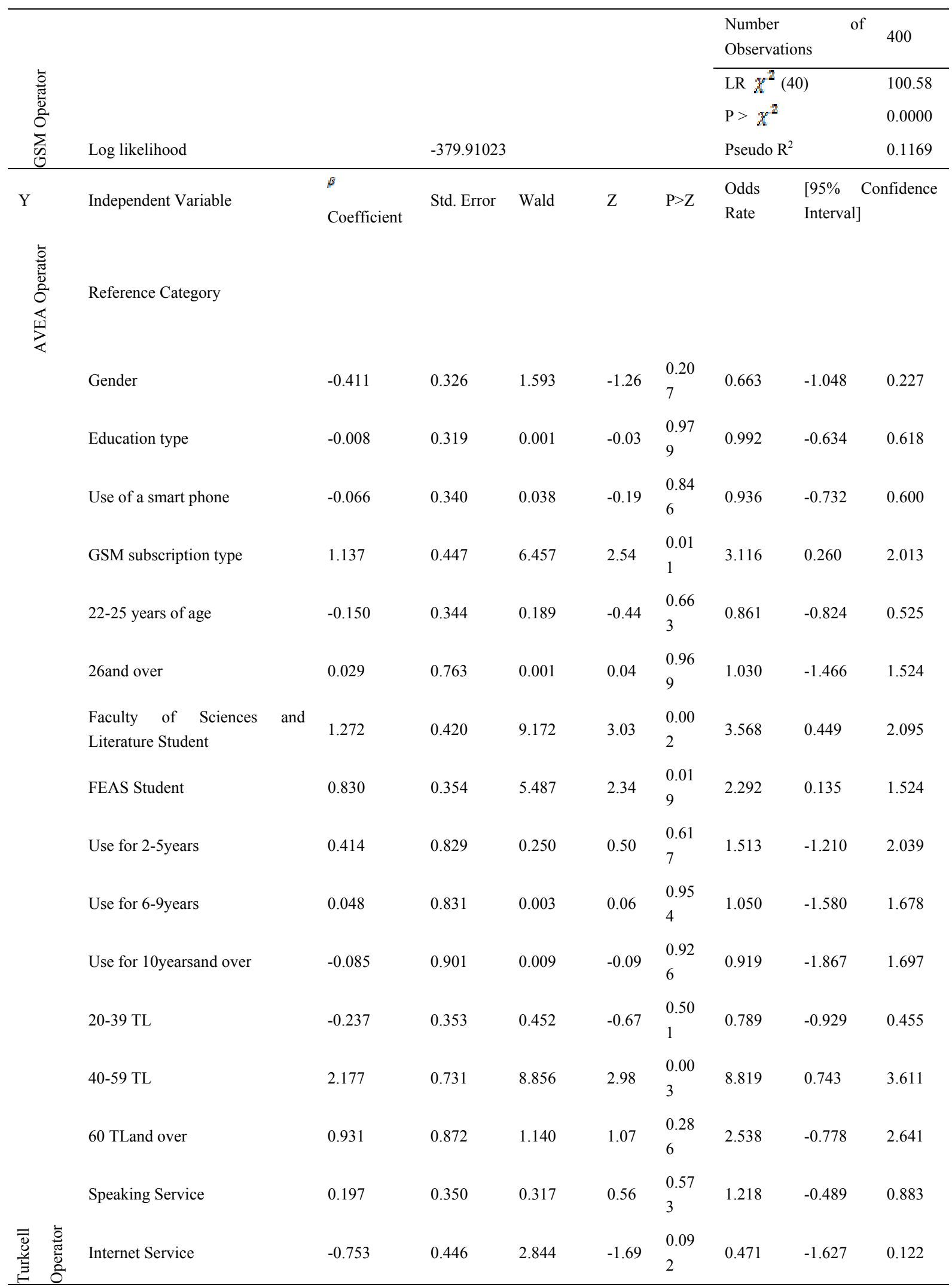




\begin{tabular}{|c|c|c|c|c|c|c|c|c|c|c|}
\hline & & $\mathrm{BF}$ & 0.456 & 0.150 & 9.276 & 3.05 & $\begin{array}{l}0.00 \\
2\end{array}$ & 1.578 & 0.163 & 0.750 \\
\hline & & FF & 0.048 & 0.147 & 0.104 & 0.32 & $\begin{array}{l}0.74 \\
7\end{array}$ & 1.049 & -0.241 & 0.337 \\
\hline & & $\mathrm{PF}$ & -0.632 & 0.153 & 17.093 & -4.13 & $\begin{array}{l}0.00 \\
0\end{array}$ & 0.531 & -0.932 & -0.333 \\
\hline & & SF & -0.119 & 0.148 & 0.639 & -0.80 & $\begin{array}{l}0.42 \\
4\end{array}$ & 0.888 & -0.409 & 0.172 \\
\hline & & Fixed & -2.653 & 1.550 & 2.928 & -1.71 & $\begin{array}{l}0.08 \\
7\end{array}$ & & -5.691 & 0.386 \\
\hline & & Gender & 0.036 & 0.273 & 0.018 & 0.13 & $\begin{array}{l}0.89 \\
4\end{array}$ & 1.037 & -0.499 & 0.571 \\
\hline & & Education type & 0.017 & 0.273 & 0.004 & 0.06 & $\begin{array}{l}0.94 \\
9\end{array}$ & 1.018 & -0.518 & 0.552 \\
\hline & & Use of a smart phone & 0.125 & 0.291 & 0.184 & 0.43 & $\begin{array}{l}0.66 \\
8\end{array}$ & 1.133 & -0.445 & 0.695 \\
\hline & & GSM subscription type & 0.241 & 0.335 & 0.518 & 0.72 & $\begin{array}{l}0.47 \\
2\end{array}$ & 1.273 & -0.417 & 0.900 \\
\hline & & $22-25$ years of age & -0.362 & 0.285 & 1.613 & -1.27 & $\begin{array}{l}0.20 \\
4\end{array}$ & 0.696 & -0.920 & 0.197 \\
\hline & & 26years and over & -0.141 & 0.665 & 0.045 & -0.21 & $\begin{array}{l}0.83 \\
2\end{array}$ & 0.868 & -1.446 & 1.163 \\
\hline & & $\begin{array}{l}\text { Faculty of Sciences and } \\
\text { Literature Student }\end{array}$ & 0.778 & 0.358 & 4.729 & 2.17 & $\begin{array}{l}0.03 \\
0\end{array}$ & 2.177 & 0.077 & 1.479 \\
\hline & & FEAS Student & 0.474 & 0.291 & 2.660 & 1.63 & $\begin{array}{l}0.10 \\
3\end{array}$ & 1.607 & -0.096 & 1.044 \\
\hline & & Use for 2-5years & -0.508 & 0.709 & 0.514 & -0.72 & $\begin{array}{l}0.47 \\
3\end{array}$ & 0.602 & -1.897 & 0.881 \\
\hline & & Use for 6-9years & -0.543 & 0.708 & 0.589 & -0.77 & $\begin{array}{l}0.44 \\
3\end{array}$ & 0.580 & -1.931 & 0.844 \\
\hline & & Use for 10 years and over & -0.669 & 0.766 & 0.763 & -0.87 & $\begin{array}{l}0.38 \\
2\end{array}$ & 0.512 & -2.169 & 0.832 \\
\hline & & 20-39 TL & -0.215 & 0.311 & 0.476 & -0.69 & $\begin{array}{l}0.49 \\
0\end{array}$ & 0.807 & -0.824 & 0.395 \\
\hline & & $40-59 \mathrm{TL}$ & 1.661 & 0.631 & 6.928 & 2.63 & $\begin{array}{l}0.00 \\
8\end{array}$ & 5.268 & 0.424 & 2.899 \\
\hline & & $60 \mathrm{TL}$ and over & -0.386 & 0.803 & 0.231 & -0.48 & $\begin{array}{l}0.63 \\
1\end{array}$ & 0.680 & -1.960 & 1.189 \\
\hline & & Speaking Service & -0.682 & 0.293 & 5.429 & -2.33 & $\begin{array}{l}0.02 \\
0\end{array}$ & 0.506 & -1.255 & -0.108 \\
\hline & & Internet Service & -0.952 & 0.350 & 7.381 & -2.72 & $\begin{array}{l}0.00 \\
7\end{array}$ & 0.386 & -1.639 & -0.265 \\
\hline & & $\mathrm{BF}$ & 0.253 & 0.126 & 4.034 & 2.01 & $\begin{array}{l}0.04 \\
5\end{array}$ & 1.288 & 0.006 & 0.499 \\
\hline & & FF & -0.023 & 0.128 & 0.031 & -0.18 & $\begin{array}{l}0.86 \\
0\end{array}$ & 0.978 & -0.274 & 0.228 \\
\hline $\begin{array}{l}0 \\
0 \\
0 \\
0 \\
0 \\
0 \\
0\end{array}$ & 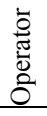 & $\mathrm{PF}$ & -0.063 & 0.130 & 0.235 & -0.48 & $\begin{array}{l}0.62 \\
8\end{array}$ & 0.939 & -0.319 & 0.192 \\
\hline
\end{tabular}




\begin{tabular}{|c|c|c|c|c|c|c|c|c|}
\hline SF & -0.122 & 0.128 & 0.907 & -0.95 & $\begin{array}{l}0.34 \\
1\end{array}$ & 0.885 & -0.373 & 0.129 \\
\hline Constant & 0.098 & 1.217 & 0.006 & 0.08 & $\begin{array}{l}0.93 \\
6\end{array}$ & & -2.287 & 2.482 \\
\hline
\end{tabular}

As seen in Table 7, the number of observations examined in the multiple logistic regression model was 400, and the model was found statistically significant as $\chi^{2}=100.58$ and $P=0.00 \times 0.01$. AVEA operator was chosen as a reference category for the purpose of identifying the effect levels of the factors influencing the GSM operator preference of the university students in the multiple logistic regression model.

In Turkcell operator preference, students were identified as studying at the Faculty of Sciences and Literature with communication expense of $60 \mathrm{TL}$ and over. Brand factor and promotion factor variables were at the significance level of 0.01, and GSM subscription type and the FEAS faculty students' variable was at the significance level of 0.05 . Internet service variable was at the significance level of 0.10 , which is statistically significant.

In Vodafone operator preference, students were identified as studying at the Faculty of Sciences and Literature with communication expense of $60 \mathrm{TL}$ and over. Communication expenses and Internet service variable was found to be at 0.01 significance level. The faculty was specified as the Faculty of Sciences and Literature, speaking service and brand factor variables were at 0.05 significance level, which is statistically significant.

Given the odds ratios:

In Turkcell operator preference: when GSM subscription type is prepaid, it is $\boldsymbol{E}^{1.185}=3.116$ times more likely to prefer Turkcell operator than postpaid line owners. In terms of the faculty, students studying at the faculty of sciences and literature and faculty of economics and administrative sciences are more likely to prefer Turkcell than those studying at the faculty of engineering (the likelihood of preference is $e^{1.272}=3.568 v \in e^{0.989}=2.292$ times higher). The students having a communication expense of 40-59 TL are more likely $\left(\varepsilon^{2157}=8.819\right.$ thmes $\left.h / g h e n\right)$ to prefer Turkcelloperator than those with a communication expense less than $20 \mathrm{TL}$. It has been observed that one unit of increase in the brand factor variable also leads to an increase in the likelihood $\left(e^{0.485}=1.578 \mathrm{t} / \mathrm{mes}\right.$ higher $)$ of preferring Turkcell operator. On the contrary, given the most frequent service use, it has been observed that Internet service decreases the likelihood of preferring Turkcell operator compared to the texting service $\left(e^{-0.52}=0.471 \cdot(1-0.471)=0.529 * 100=\% 52.9\right.$, successively) Similarly, a unit of increase at the promotion factor variable has been observed to decrease the likelihood of preferring the Turkcell operator $\left(e^{-0.62}=0.531 .(1-0.531)=0.469 * 100=9 / 646.9\right)$.

In Vodafone operatorpreference: the likelihood of the students studying at the Faculty of Sciences and Literature to prefer Vodafone operator is higher than those studying at the faculty of engineering ( $e^{0.5 s}=2,177$ ). The students having a communication expense of 40-59 TL are more likely $\left(e^{1.6 \mathrm{CL}} \mathbf{- 5 . 2 6 0}\right.$ ) to prefer Vodafone operator than those with a communication expense less than $20 \mathrm{TL}$. It has been observed that one unit of increase in the brand factor variable also leads to an increase in the likelihood ( operator. On the contrary, given the most frequent service use, it has been observed that speaking and Internet service decreases the likelihood of preferring Vodafone operator compared to the texting service (

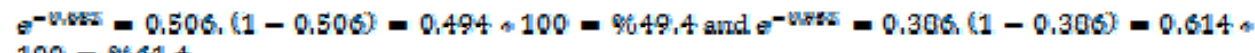

successively).

\section{Conclusion}

The aim of this study was to identify the most influential factors among demographic, socio-economic, brand, fee, promotion and service factors, and the effect levels of these factors on university students' GSM operator preferences. Data obtained from the survey was gathered from 400 students studying at Osmaniye Korkut Ata University by the use of a questionnaire. Factor analysis was performed at the analysis part with the use of SPSS 
18 software. Multiple logistic regression analysis was used with the Stata 11 software in order to determine the effect levels of these factors and the demographic and socio-economic factors. As a result of the analyses, of all the students participating in the survey were observed to be using Avea (41\%), Vodafone (35\%) and Turkcell (24\%) GSM operators, successively. Avea has been chosen as a reference category for identifying the effect levels of the factors. It has been observed that communication expense is the most important variable among socio-economic factors for the GSM operator preference, whereas the brand factor has been found to be the most important factor in making the GSM operator purchasing decision. The most important variables, which are also effective and statistically significant, are communication expenses, GSM subscription type, the service type received from the operator, and the brand factor for preferring Turkcell and Vodafone operators.

In this study, it is specified that Turkcell operator is less likely to be preferred by men to women, evening education students to daytime education students, non-smart phone users to smart phone users, longer years of a mobile ownership to shorter years of a mobile ownership, people with a communication expense of 20-39 TL to those having less than $20 \mathrm{TL}$, students using the internet service to those using the texting service. It has also been found that brand and fee factors increase the preference possibility of Turkcell operator, while promotion and service factors decrease it. On the other hand, it has been specified that Vodafone operator is more likely to be preferred by men to women, evening education students to daytime education students, non-smart phone users to smart phone users, students with a prepaid line to postpaid line in terms of GSM subscription type, students at the Faculty of Sciences and Literature and the Faculty of Economics and Administrative Sciences to the Faculty of Engineering, students with a communication expense of 40-59 TL to those having less than $20 \mathrm{TL}$. The brand factor increases the preference possibility of Vodafone operator, while fee, promotion and service factors decrease it. It is also possible to assert that the effect level of the brand factor of Turkcell operator is higher than that of Vodafone's.

In conclusion, these decisions made through identifying the most important factors that influence the university students' GSM operator preference are considered to be beneficial in sales-related activities of GSM operators in the future.

\section{References}

Arzu, A., \& Önder, H. (2013). Farklı veri yapılarında kullanılabilecek regresyon yöntemleri. Anadolu Tarım Bilimleri Dergisi, 28(3), 168-174. http://dx.doi.org/10.7161/anajas.2013.28.3.168

Atmaca, E., \& Keskin, M. (2014). GSM operatörlerine yönelik müşteri memnuniyet araştırması. Çukurova Üniversitesi İktisadi ve İdari Bilimler Fakültesi Dergisi, 18(1), 44-63.

Aydın, S., Özcan, M., \& Yücel, R. (2007). Türk GSM sektöründe abonelerin sadakat tutumu ve değiştirme maliyetinin rolü. Süleyman Demirel Üniversitesi İktisadi ve İdari Bilimler Fakültesi Dergisi, 12(2), 19-34.

Barutçu, S. (2007). GSM sektöründe müşteri bağl1lı̆̆1 (Pamukkale üniversitesi öğrencilerinin GSM operatörlerine bağlılıkları ve bağl11ıklarını etkileyen faktörler). Afyon Kocatepe Üniversitesi I.I.I.B.F. Dergisi, 9(1), 48-72.

Bilgi Teknolojileri ve İletişim Kurumu. (2013). Ü̧̧ aylık pazar verileri raporu. Retrieved from http://www.btk.gov.tr/kutuphane_ve_veribankasi/pazar_verileri/ucaylik14_3.pdf

Dadzie, A., \& Boachie-Mensah, F. (2011). Brand preference for mobile phone operator services in the Cape Coast Metropolis. International Journal of Business and Management, 6(11), 190-205. $\mathrm{http}: / / \mathrm{dx}$. doi.org/10.5539/ijbm.v6n11p190

Dündar, S., \& Fatih, E. (2008). Öğrencilerin GSM operatörü tercihinin, analitik hiyerarşi süreci yöntemiyle belirlenmesi. Yönetim ve Ekonomi: Celal Bayar Üniversitesi İktisadi ve İdari Bilimler Fakültesi Dergisi, 15(1), 195-205.

Erginel, N., Çakmak, T., \& Şentürk, S. (2010). Numara taşınabilirliği uygulaması sonrası Türkiye'de GSM operatör tercihlerinin bulanık topsıs yaklaşımı ile belirlenmesi. Anadolu Üniversitesi Bilim ve Teknoloji Dergisi, 11(2), 81-93.

Felek, S., Yuluğkural, Y., \& Aladağ, Z. (2002). Mobil iletişim sektöründe pazar paylaşımının tahmininde AHP ve ANP yöntemlerinin kıyaslanması. Endüstri Mühendisliği Dergisi, 18(1), 6-22.

Field, A. (2009). Discovering statistics using spss. Sage Publications.

Gautam, V., \& Kumar, M. (2011). An empirical investigation of factors determining the consumers' choice of mobile service providers. İşletme Araştırmaları Dergisi, 3(4), 3-17. 
Hassan, N., Ahmad, N., \& Aminuddin, W. M. W. (2013). Selection of mobile network operator using analytic hierarchy process (ahp). Advances in Natural and Applied Sciences, 7(1), 1-5.

Hemmati, S., Shapouri, F., \& Keramati, A. (2013). Evaluating the Iran mobile communication operators by analytical network process (ANP). Journal of Telecommunications System \& Management, 2(1), 1-8.

Hosmer, D. W., \& Lemeshow, S. (2000). Appliedlogisticregression. John Wiley \& Sons.

http://www.tuik.gov.tr/UstMenu.do?metod=temelist

http://www.turkcell.com.tr/tr/hakkimizda/yatirimci-iliskileri/turkiye-gsm-pazari

Karaçuka, M., Çatık, A. N., \& Haucap, J. (2013). Consumer choice and local network effects in mobile telecommunications in Turkey. Telecommunications Policy, 37(4), 334-344. http://dx.doi.org/10.1016/j.telpol.2012.10.005

Karagöz, Y., Çatı, K., \& Koçoğlu, C. M. (2009). Cep telefonu ve operatör tercihinde etkili olabilecek faktörlerin demografik özelliklere bağlı olarak irdelenmesi. Dumlupınar Üniversitesi Sosyal Bilimler Dergisi, 5(23), $7-24$.

Kızgın, Y. (2008). Genç GSM abonelerinin operatör seçimlerini etkileyen değişkenlerin konumlandırılması üzerine bir alan araştırması: Muğla Üniversitesi öğrencileri örneği. Yönetim Ve Ekonomi Araştırmaları Dergisi, 6(10), 142-161.

Kleinbaum, D. G., \& Klein, M. (2010). Logistic regression: A self-learning text. Springer Science \& Business Media. http://dx.doi.org/10.1007/978-1-4419-1742-3

Maksüdünov, A. (2014). Kırgızistan GSM sektöründe operatör tercihini etkileyen faktörlerin belirlenmesi. Manas Sosyal Araştırmalar Dergisi, 3(10), 59-78.

Murthy, M. K., \& Varalakshm1, S. (2011). Mobile service provider-A study with special reference to Nawaras LLC. International Journal of Research In ComputerApplication\& Management, 1(5), 16-22.

Ofwona, C. (2007). Factorswhich determine individual consumer choice of mobile telephone service providers in the city of Nairobi (Doctoral dissertation, School of Business, University of Nairobi).

Okeke, C. I. (2014). Majorfactors influencing the choice of GSM network among oil and gas workers in Port Harcourt, Nigeria. International Journal of Emerging Knowledge, 2(1), 8-22.

Olatokun, W., \& Nwonne, S. (2012). Determinants of users' choice of mobile service providers in the Nigerian telecommunications market. AfricanJournal of Computing \& ICT, 5(4), 19-32.

Özdamar, K. (2009). Paket programları ile istatistiksel veri analizi. Cilt I, Kaan Kitapevi: Eskişehir.

Özer, H. (2004). Nitel değişkenli ekonometrik modeller: Teori ve bir uygulama. Nobel Yayın Dağıtım: Ankara.

Özer, H., Özçomak, M. S., \& Oktay, E. (2006). Üniversite öğrencilerinin cep telefonu hat tercih olasıllı̆ının belirlenmesi: Atatürk üniversitesi örneği. Gazi Üniversitesi İIBF Dergisi, 7(2), 1-11.

Öztürk, A., Göral, R., \& Cici, E. N. (2013). Satış geliştirme faaliyetlerinin genç tüketicilerin satın alma davranışlarına etkisi: Selçuk üniversitesi öğrencilerinin gsm markaları tercihleri üzerine bir araştırma. Sosyal ve Beşeri Bilimler Dergisi, 5(2), 1-10.

Pakola, J., Pietila, M., Svento, R., \& Karjaluoto, H. (2003). An investigation of consumer behaviour in mobile phone markets in Finland. Submissionto $32^{\text {nd }}$ EMAC Conference, Track: New Technologies and E-Marketing.

Paulrajan, R., \& Rajkumar, H. (2011). Service quality and customers preference of cellular mobile service providers. Journal of Technology Management \& Innovation, 6(1), 38-45. http://dx.doi.org/10.4067/s0718-27242011000100004

Rahman, S., Haque, A., \& Ahmad, M. I. S. (2010). Exploringinfluencing factors for the selection of mobile phone service providers: A structural equational modeling (sem) approach on Malaysianconsumers. AfricanJournal of Business Management, 4(13), 2885-2898.

Savaşçı, İ., \& Günay, G. N. (2008). İşletmelerin rekabet üstünlüğü sağlamalarında müşteri değerinin yaratılması: GSM operatörlerinin üniversite öğrencilerine sundukları hizmet algılamalarına yönelik bir değerlendirme. Erciyes Üniversitesi İktisadi ve İdari Bilimler Dergisi, 30, 251-274.

Shah, C. (2012). Consumer preferences for mobile service providers: An empirical study in Bardoli. International Journals of Marketing and Technology, 2(8), 269-288. 
Türe, M., Kurt, İ., Yavuz, E., \& Kürüm, A. T. (2005). Hipertansiyonun tahmini için çoklu tahmin modellerinin karşılaştırılması (sinir ağları, lojistik regresyon ve esnek ayırma analizleri). Anadolu Kardiyoloji Dergisi, 5, 24-28.

Ulaşanoğlu, M. (2005). GSM sektöründe hizmet kalitesi: Müşteri memnuniyeti ölçümü ve öneriler. Telekomünikasyon Kurumu, Uzmanlık Tezi, Ankara.

Ürük, E. (2007). İstatistiksel uygulamalarda lojistik regresyon analizi (Yayınlanmamış Yüksek Lisans Tezi). Marmara Üniversitesi Fen Bilimleri Enstitüsü, İstanbul.

\section{Copyrights}

Copyright for this article is retained by the author(s), with first publication rights granted to the journal.

This is an open-access article distributed under the terms and conditions of the Creative Commons Attribution license (http://creativecommons.org/licenses/by/4.0/). 